\title{
Economic crisis and its influences on the interaction between land use and transport in Madrid Region
}

\author{
Yang Wang \\ Ph.D, TRANSyT-UPM, Spain \\ Andres Monzon \\ Professor, TRANSyT-UPM, Spain
}

\section{INTRODUCTION}

Land-use system and transport system are closely linked. The relationship between the two systems has been studied since 1960s (Harris 1965; Lee 1973; Batty 1994; Harris 1994; Hayashi \& Kenji, 1989; Wegener, 2004). The previous studies found the distribution of land uses, such as residential, industrial or commercial, determines the locations of people activities like living, working, shopping, education or leisure; on the contrary the distribution of people activities requires trips in the transport system to overcome the distance between the locations of activities (Wegener, 1999). However, there are apparently new changes on this typical relationship between land use and transport during the economic crisis (Geels, 2013).

During the last decade, Spain fell into a great recession from a fast economic growing during the 90s to 2006. Between October 2007 and October 2008, Spain had its unemployment rate climb $36 \%$, exceeding by far the unemployment surge of past economic crises like 1993 (Suarez, 2010). Spanish government therefore launched a series measures as called austerity packages in order to restore its credibility and reduce the budget deficit (Elteto, 2011).

The consequences of the crisis on land use and transport include reduced housing price, less travel demand, stagnant car ownership and increased public transport fare, etc. However, it is not clear how the economic crisis influences the interaction between land uses and transport, particularly the influences at different spatial scale. Therefore, this paper aims to find out if a statistical analysis of land uses and mobility can help to answer the question of what happens during economic crisis on both two systems, and unveiling key spatial relationships between them.

The methodology for the analysis is developed accordingly with the data and resources available. First, an exploratory data analysis (EDA) is performed in order to identify the land use and mobility pattern during the last decade. Land use is defined in terms of the characteristics of the residential location of the individuals: population density, distribution of workplaces and employees, and other economic indicators. The second aspect consists on crossing the spatial patterns of the different aspects in order to find some explanatory 
relationships that indicate the presence of the key characteristics.

The study is based on the case of Madrid Region. The land-use and transport data presented in this analysis are from 2004 to 2014, which are collected from the national statistical institute, the regional government database and two urban mobility surveys of Madrid (i.e., EDM'04 and ESM'14). The EDM'04 was collected 34,942 samples through several measures (i.e, telephone, mail, internet and personal interview) from the whole Madrid Region. And the ESM'14 has around 4500 samples, and the measures to collect the data include internet and telephone.

The remainder of the paper is organized as follows. The next section first provides an updated mechanism of land use and transport interaction during the crisis. Then, it begins with the analysis of the influences of the economic crisis, on the land use changes and on the mobility changes. The results of the cross analysis are also presented and discussed in this part. Last, concluding remarks are offered.

\section{An updated mechanism}

A typical mechanism of the interaction between land use and transport is that the economic growth raise trip demand as the result of increased production and income growth, and higher income stimulates car ownership and leads more car-dependency (Hayashi, 2003). Yet, a great economic recession causes a different pattern of the interaction between land use and transport. The updated mechanism is illustrated in Figure 1.

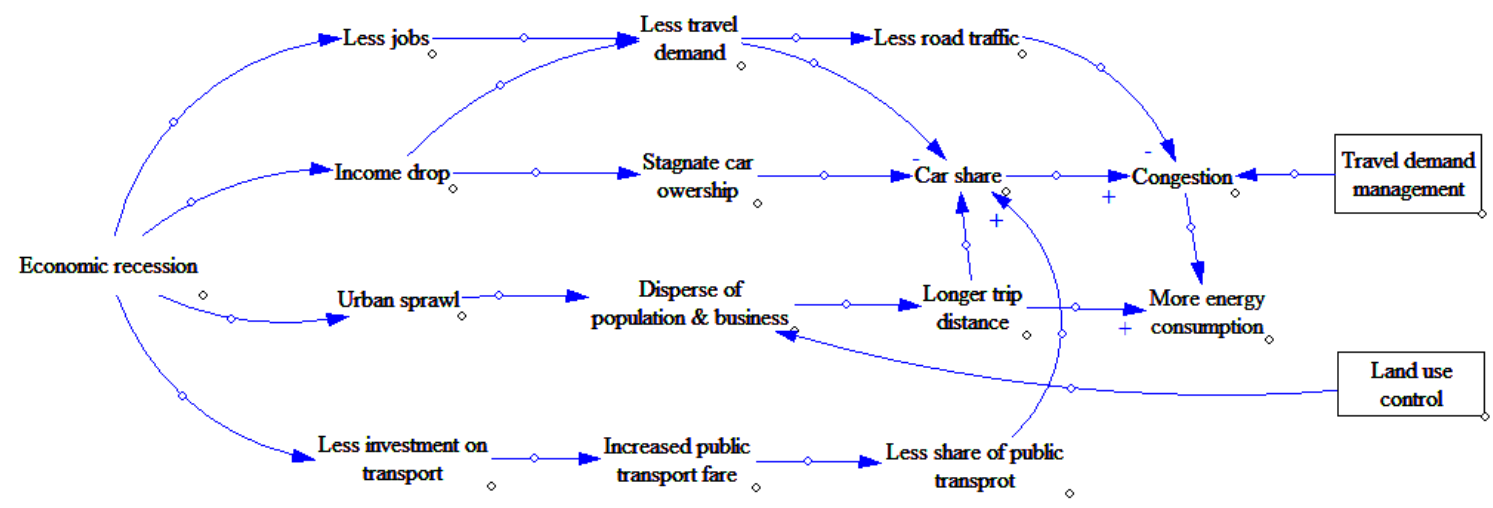

Fig.1 - Mechanism of the interaction between land use and transport in crisis

The economic recession leads people moving to cheaper place to live which causes suburbanization. The dispersed relocation of population and housing encourages longer trip distance. Travel demand decreases due to income reducing and high unemployment. At the same time, government reduces the investment to subside the public transport which worse the service. Eventually, longer trip distance and less public transport share causes the problems like congestion and high energy consumption which indeed require government's interventions. 
Although the travel demand is reducing, it is not clear the influences of the economic crisis on the interaction of land use and transport. The follow part therefore elaborates the analysis using the statistical data collected from Madrid region.

\section{URBAN SPRAWL AND LONG DISTANCE TRIP}

\subsection{The economic crisis on urban sprawl}

Figure 2 presents the map of Madrid region that is distinguished in three studies area, i.e., the main city, the metropolitan ring and the regional ring. Table 1 shows the economic indices including number of residents and employees, population density, jobs and average housing price in respect of the three areas of Madrid.

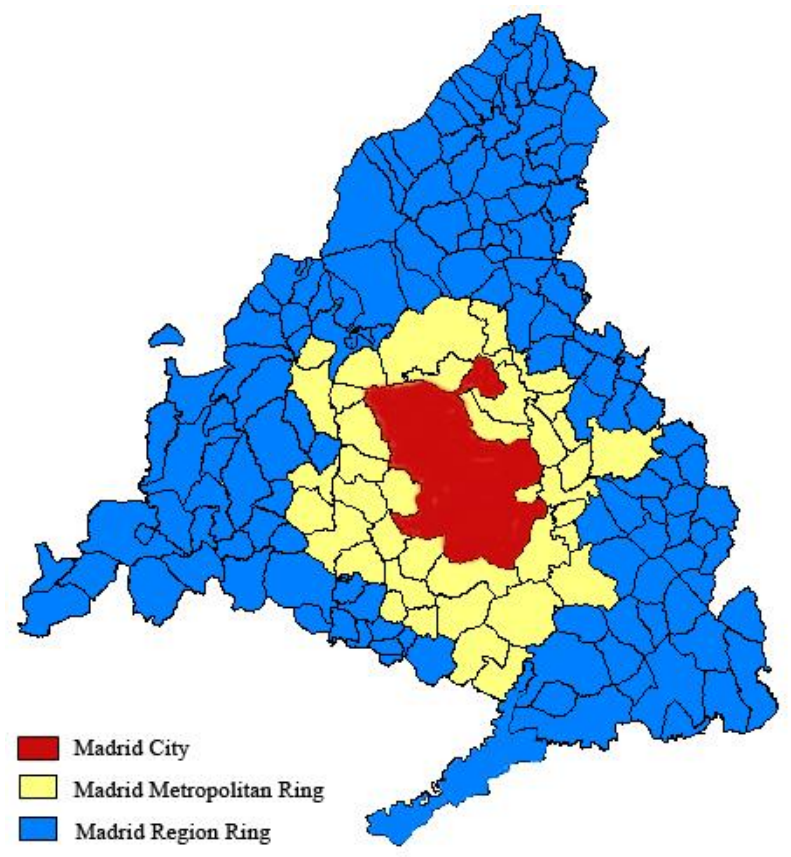

Fig. 2 - Madrid Region Map

\begin{tabular}{|l|c|c|c|c|}
\hline \multirow{2}{*}{ Year } & Whole Region & $\begin{array}{c}\text { In Region } \\
\text { Ring }\end{array}$ & $\begin{array}{c}\text { In Metropolitan } \\
\text { Ring }\end{array}$ & $\begin{array}{c}\text { In Main } \\
\text { City }\end{array}$ \\
\cline { 2 - 5 } & \multicolumn{4}{|c|}{$\mathbf{N}^{\mathbf{0}}$ of Residents } \\
\hline 2004 & $5,867,299$ & 350,110 & $2,354,885$ & $3,162,304$ \\
\hline 2014 & $6,518,768$ & 467,579 & $2,797,454$ & $3,253,735$ \\
\hline & \multicolumn{4}{|c|}{ Population Density (1000 person/km2) } \\
\hline 2004 & 4020 & 132 & 1606 & 14410 \\
\hline 2014 & 4134 & 195 & 1854 \\
\hline \multicolumn{5}{|c|}{$\mathbf{N}^{\mathbf{0}}$ of Employees } \\
\hline 2004 & $2,706,922$ & 156,068 & $1,117,657$ & $1,433,197$ \\
\hline 2014 & $2,163,442$ & 144,551 & $1,033,725$ & 985,166 \\
\hline \multicolumn{5}{|c|}{$\mathbf{N}^{\mathbf{0}}$ of Workplaces } \\
\hline 2004 & $2,215,806$ & 63,587 & 710,689 & $1,441,530$ \\
\hline 2014 & $2,523,666$ & 87,161 & 913,490 & $1,523,015$ \\
\hline \multicolumn{5}{|c|}{$\mathbf{N}^{\mathbf{0}}$ of Dwellings } \\
\hline 2004 & $2,451,272$ & 198,417 & 816,431 & $1,436,424$ \\
\hline 2014 & $2,894,680$ & 278,370 & $1,085,360$ & $1,530,950$ \\
\hline
\end{tabular}




\begin{tabular}{|c|c|c|c|c|}
\hline & \multicolumn{4}{|c|}{ Average Housing price $\left(€ / \mathrm{m}^{2}\right)$} \\
\hline 2004 & 2,576 & 2,076 & 2,361 & 3,401 \\
\hline 2014 & 2,335 & 1,838 & 2,051 & 2,911 \\
\hline
\end{tabular}

Table 1 -Economic indices of Madrid in 2004 and 2014 (INE, IEM)

During the economic crisis, Spain's unemployment rate hit $17.4 \%$ at the end of March 2009 , with the jobless total now having doubled over 2008, when two million people lost their jobs (Suarez, 2010). Similarly, 20\% more unemployment arise in Madrid Region, particularly in the main city ( $31 \%$ less employees), although the number of workplaces is increasing as a result of a number of small companies emerged. After the property bubble burst in Spain, the housing price drops 9\% in Madrid, especially in the main city $(14 \%$ less) and the metropolitan ring (13\% less). These economic indices show a notable economic recession in Madrid region in the last decade.

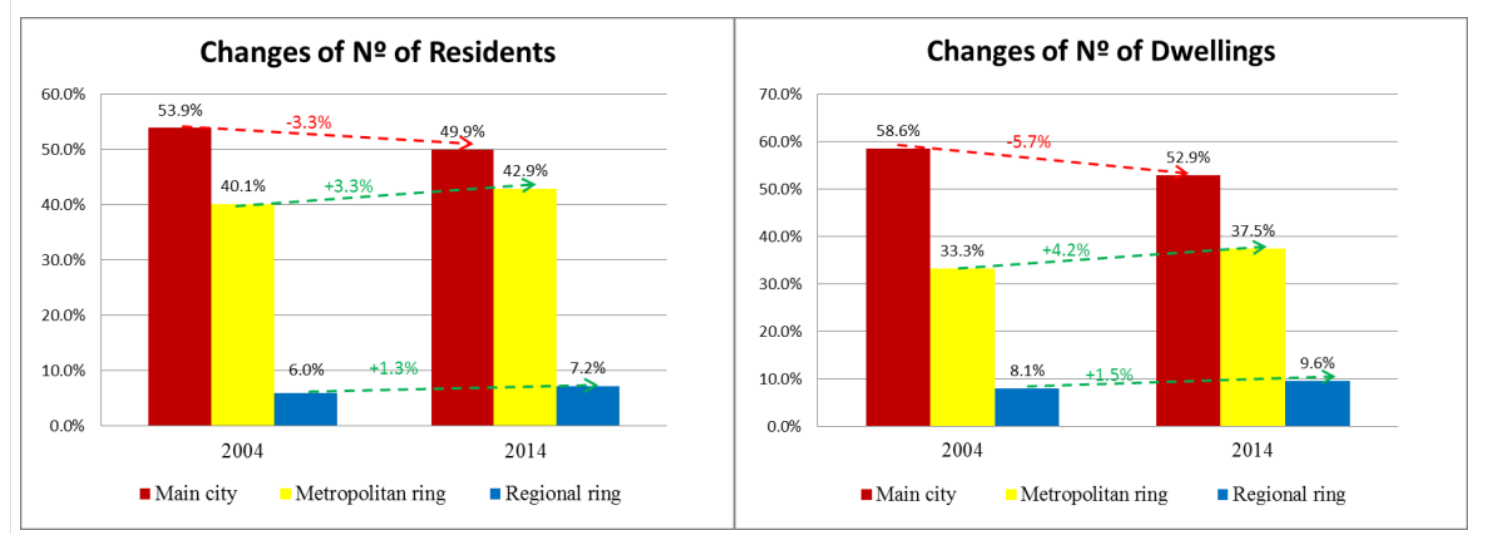

Fig. 3 - The changes of the proportion of residents and dwellings of Madrid in 2004 and 2014 (IEM)

Figure 3 shows the changes of the spatial distribution of residents and dwellings between 2014 and 2004. In total, there are 651 thousand more residents and 443 thousand of new dwellings grown during the decade of 2004 - 2014. It can be seen a number of residents move out from main city to the suburb where $79 \%$ of new houses were constructed during the last decade. It leads to the population density slightly reduced in the main city and extremely increased in the regional ring (47\% more) and in the metropolitan ring (15\%) of Madrid region (table 1).

Owing to the lower land price in the periphery of the region, there is $18 \%$ new dwellings were built in this area and meanwhile attract $18 \%$ of new residents live here. The metropolitan ring and the regional ring has $4.2 \%$ and $1.5 \%$ respectively more proportion of new dwellings and drew around $67.9 \%$ new residents. On the contrary, the main city of Madrid lost 3.3\% proportion of residents and 5.7\% proportion of dwellings. Comparing with the average increasing rate of population from 2004 to 2014, a large number of people move to the periphery of the region and the urban sprawl indeed occurred. 


\subsection{The economic crisis on mobility changes}

Table 2 lists the mobility changes in Madrid between 2004 and 2014. It clearly shows that the total travel demand significantly reduced as a result of economic recession. There is $11 \%$ less trips per day in 2014 comparing with 2004, and $29 \%$ work related trips reduced. At the same time people of Madrid reduced their daily trips from 2.5 to 2 times per day. And the average car occupancy changed from 1.28 to 1.56 , which implies there are less single drivers now. As household income is declined from 2009, and unemployment rate breaks the highest records several times, it all leads travel demand reducing.

\begin{tabular}{|l|c|c|c|c|c|}
\hline Year & $\begin{array}{c}\mathrm{N}^{\circ} \text { of } \\
\text { trips/day }\end{array}$ & $\begin{array}{c}\mathrm{N}^{\circ} \text { trips per } \\
\text { person/day }\end{array}$ & $\begin{array}{c}\text { Average car } \\
\text { occupancy }\end{array}$ & $\begin{array}{c}\mathrm{N}^{\circ} \text { of trips to } \\
\text { work or related }\end{array}$ & $\begin{array}{c}\text { Approximated } \\
\text { average trip } \\
\text { Distance } \\
\text { (Kilometer) }\end{array}$ \\
\hline 2004 & $14,511,398$ & 2.5 & 1.28 & $4,412,403$ & 11.04 \\
\hline 2014 & $12,925,061$ & 2.0 & 1.56 & $3,132,237$ & 12.12 \\
\hline
\end{tabular}

Table 2 - Mobility changes of Madrid in 2004 and 2014 (EDM'04 and ESM'14)

Taking account the average trip distance, it is approximately calculated as Equation (1).

$$
d=\frac{\sum_{i=1, j=1}^{90} D_{i j} * T_{i j}}{\sum_{i=1, j=1}^{90} T i j}
$$

$D_{i j}$ is the distance between geometric centroid of every two municipalities (i.e., $i$ and $j$ ) of Madrid; $T_{i j}$ is the total number of trips between municipality $i$ and $j$. It can be seen that although the average trip length has only $10 \%$ increasing, there is $16 \%$ total trip distance increasing in Madrid, particularly among the metropolitan ring (65\% more) and regional ring (20\% more). The effect of urban sprawl on trip distance is high. 


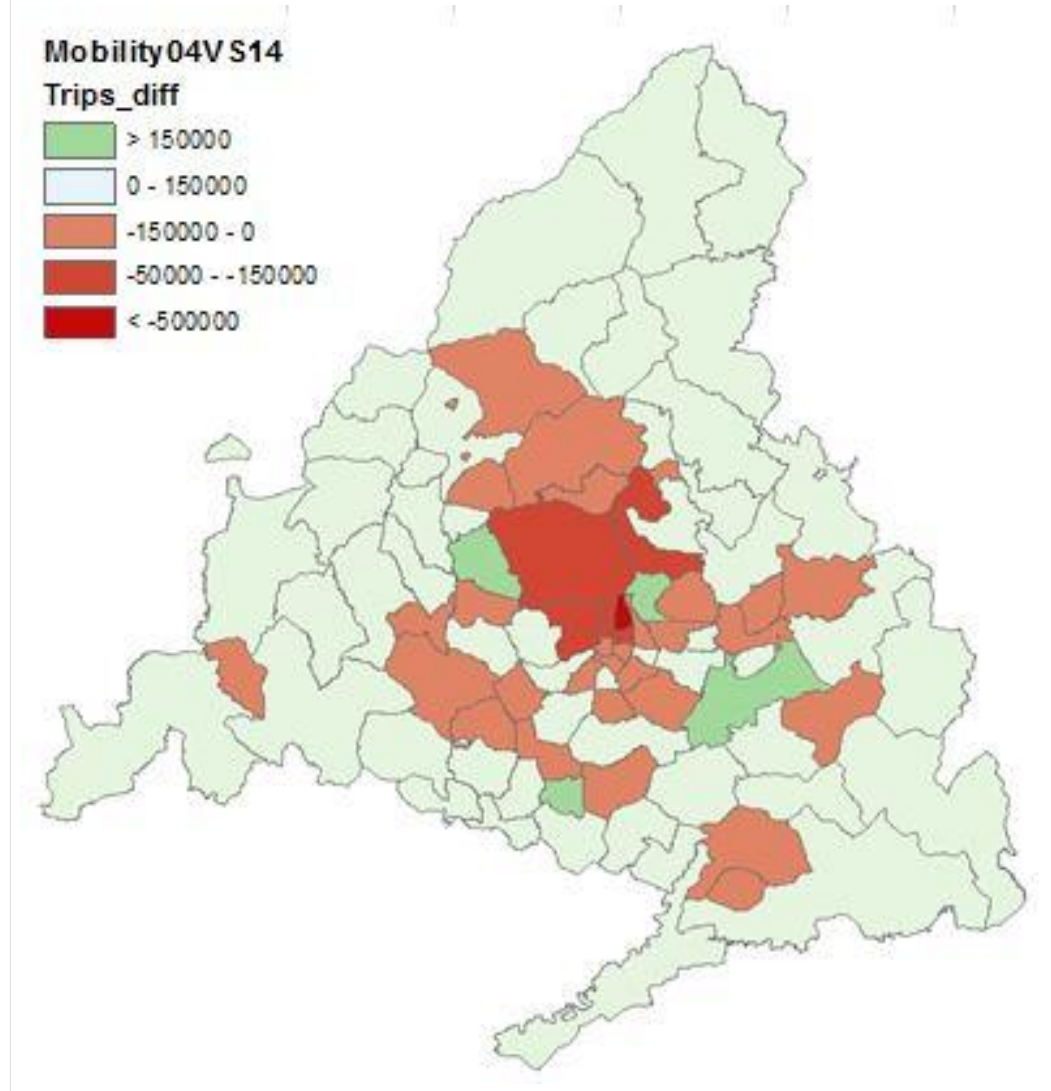

Fig 4 - Changes of the total number of trips 2014-2004 (EDM'04 and ESM'14)

Study on the spatial changes of mobility, figure 4 illustrates the changes of the total number of trips between 2004 and 2014. The green color means trip increasing and the red is trip reduction. There are a great number of trips reductions in the main city and metropolitan ring of Madrid, however, the total trip increased in the region ring of Madrid and some areas of the metropolitan ring. It leads to longer trip distance which implies more energy consumption and more negative external effects.

\section{ECONOMIC RECESSION AND MODAL SHARE}

This part presents the economic indices; following on that figure 5 illustrates the relationship of the gross domestic product (GDP) and car ownership growth by year on the basis of 2003. Owing to the economic recession, the GDP of Madrid started dropping from 2009. Consequently the car ownership has reduced in 2007 and kept the same level during the whole period of the economic crisis. 


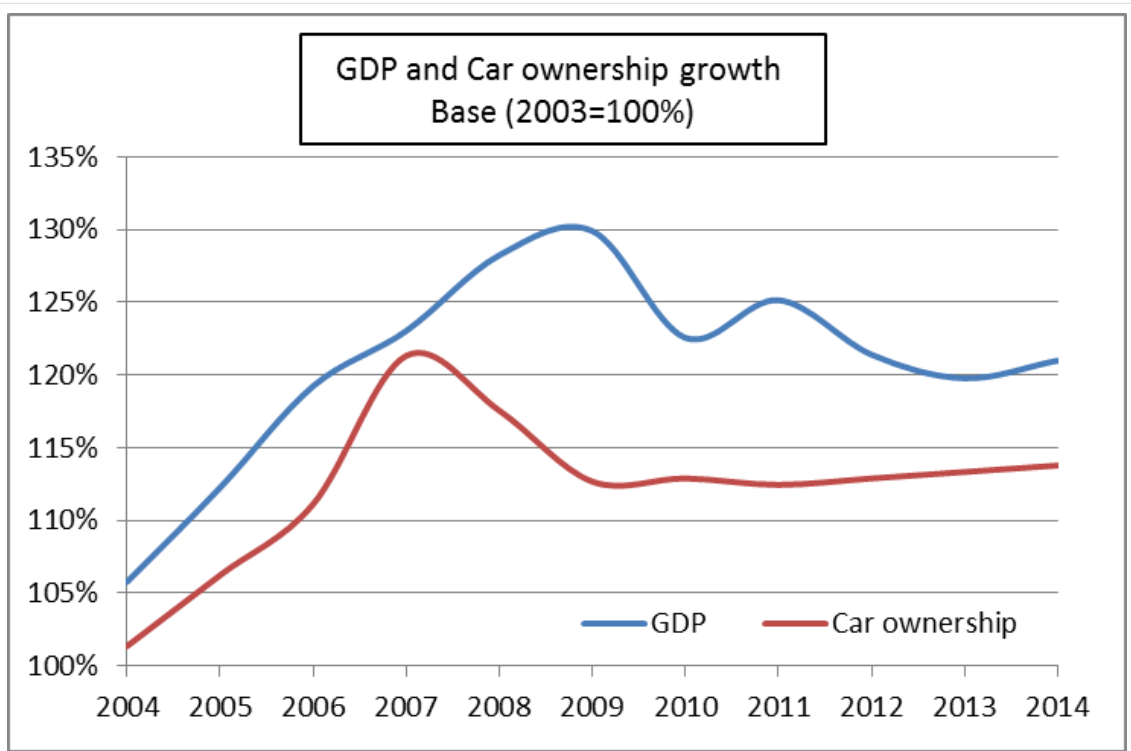

Fig 5 - GDP and employment changing from 2001 to 2014 in Madrid (IEM)

The reduced GDP leads people containing the cost of living, including the transport spending, which is corresponding with the reduced travel demand that is shown in table 2. However, the decreased income and car ownership of Madrid does not lead less car sharing. Table 3 presents the percentages of the modal share of the three study areas of Madrid.

\begin{tabular}{|c|c|c|c|c|c|c|c|c|}
\hline & \multicolumn{2}{|c|}{ Whole Region } & \multicolumn{2}{c|}{ Regional ring } & \multicolumn{2}{c|}{$\begin{array}{c}\text { Metropolitan } \\
\text { Ring }\end{array}$} & \multicolumn{2}{c|}{ Main city } \\
\hline Year & 2004 & 2014 & 2004 & 2014 & 2004 & 2014 & 2004 & 2014 \\
\hline Car (\%) & 35.4 & 41.0 & 53.8 & 68.3 & 44.5 & 53.0 & 28.1 & 30.0 \\
\hline PT (\%) & 32.5 & 27.8 & 14.4 & 10.9 & 20.8 & 16.0 & 41.4 & 37.8 \\
\hline Walking (\%) & 31.2 & 29.9 & 31.7 & 20.8 & 34.4 & 30.0 & 29.1 & 30.7 \\
\hline Others (\%) & 0.9 & 1.3 & 1.0 & 0.02 & 0.3 & 1.0 & 1.3 & 1.6 \\
\hline
\end{tabular}

Table 3 - Percentages of modal share of Madrid in 2014 and 2004 (EDM'04 and ESM'14)

As it shown in Table 3, there is a great decreasing (4.7\% less) on the public transport (PT) share in Madrid. The main reason caused the drop of PT share is the worse of PT service. As the consequence of economic crisis, Spanish government launched a series of austerity packages including reduce the subsidy to public transport operations. From 2009 to 2014, the single PT ticket in Madrid has increased 30\% and monthly ticket increased around $60 \%$, the biggest rise in 10 years. At the same time, the frequency of bus and metro is reduced. Owing to these reasons, more and more travelers have shifted to car using $(5.6 \%$ more) for the last decade. 
It is interesting to observe the data in differ territorial scale. In the regional ring, as the population density (table 1) increasing and longer trip distance, there are $14.5 \%$ more trips made by car and $3.5 \%$ less trips by public transport and almost $11 \%$ less by walking. Similar changes appeared in the metropolitan ring, more car sharing and less PT and walking share. In the main city, the changes of modal share are a bit different. There are more travelers (3.6\% more) choose to walk or using other mode (i.e., taxi, bicycle, carpooling, etc.) instead of using car of public transport. Thus, the increasing of car share is less than the average, and more share of walking mode. Similar found appears in the modal share for work related trips, a big increase in car share, and deceasing for public transport share mainly owing to the high raised tariffs.

\section{CONCLUSIONS AND DISCUSSIONS}

In summary, this study indicates that economic recession does influence on land use characteristics and mobility system as well as the interaction between them. Travel demand declines and trip distance increases as population and business disperse. GDP as an indicator for economic activity is important in determining mode share and car ownership.

Most significantly, as the level of PT service decreases, the use of public transport decreases and car use increase in the whole region. It leads more congestion and energy consumption. In addition, public service level decline, as measured by bus frequency and fare appears to be a more important determinant of mode choice than car ownership. Finally, long trip distance and more car share are key factors of road traffic. It encourages more energy consumption and discourages non-motorization mode like walking or cycling.

These results show a close link between land use and transport and have clear implications for transport policy and sustainability. The economic crisis is a double-edged sword, it is damage but it is also an opportunity. For policy maker, it is important to attempt to launch certain policy measures like travel demand management or land use control to solve the problems. Travel demand management measures like reducing car use, better public transport service can encourage more sustainable travel patterns. Land use control such as compact land use development can restrain widely outspread residential development.

For future study, we will investigate on the land use impacts of the local access to public services and other activities like shopping and leisure; the mobility influence like urban congestion. Moreover, study on the energy consumption and comparing the influence of Madrid with another city of Spain, like Barcelona is also expected.

\section{REFERENCES}

BATTY, M. (1994). A Chronicle of Scientific Planning: The Anglo-American Modeling Experience. Journal of the American Planning Association 60, pp. 7-16. 
Consorcio de Transportes de Madrid EDM'04. (2006) Encuesta domiciliaria de movilidad en día laborable 2004.

Consorcio de Transportes de Madrid ESM'14. (2006) Encuesta sintética de movilidad en la comunidad de Madrid -2014

ÉLTETÖ, A. (2011). The economic crisis and its management in Spain. Eastern Journal of European Studies, 2(1), pp.41-55.

GEELS, F.W. (2013). The impact of the financial-economic crisis on sustainability transitions: Financial investment, governance and public discourse. Environmental Innovation and Societal Transitions (6), pp. 67-95.

HARRIS, B. (1965). New Tools for Planning. Journal of the American Institute of Planners 31, pp. 90-95.

HARRIS, B. (1994). Science in Planning: Past, Present, Future. Journal of the American Planning Association 60, pp.31-42.

HAYASHI, Y and Kenji D. (1992). Benefit Incidence of Outer Urban Ring Roads Theory and Case Study of the Nagoya Ring Road. Land Use, Development and Globalisation. Selected Proceedings of the Sixth World Conference on Transport Research, Lyon.

HAYASHI, Y and ROY, J (2013). Transport, land-use and the environment. Springer Science \& Business Media, pp.3-21

LEE, D.B. (1973). Requiem for Large-Scale Models. Journal of the American Institute of Planners 39, pp. 163-78.

SUAREZ, J. (2010). The Spanish crisis: background and policy challenges. CEMFI Working Paper 1005

WEGENER, M. (2004). Overview of land use transport models", in Hensher D.A., Button K.J.,Haynes K.E., Stopher P.R. (eds), Handbook of Transport Geography and Spatial Systems, Elsevier, United Kingdom, pp.127-146. 